\title{
Kafelerde Kullanıcı Memnuniyetinin Konfor Koşulları Açısından Değerlendirilmesi: Görükle/Bursa Örneği
}

\author{
Emel GÜVEN ${ }^{1 *}$, Filiz ŞENKAL SEZER $^{2}$
}

Öz

Kafeler insanların boş zamanlarını değerlendirip, dinlendikleri, bir şeyler yiyip içerek sosyalleştikleri mekânlardır. Kafeler çeşitli toplumsal işlevleri yerine getirir. Hizmet ve kültür kurumu olarak, geçmiş yıllarda olduğu gibi günümüzde de dönemin ekonomik ve toplumsal gelişmelerine uygun olarak yeni hizmetleri karşılar. Bu araştırmada, "İnsanların günlük hayatta sıkça tercih ettikleri kafe mekânlarında ki yapısal konfor koşullarının uygulanmasıyla, kullanıcının psikolojik açıdan çevresinden memnunluk duyarak fiziksel performansını üst düzeye çıkarması sağlanacaktır." hipotezi ortaya konmuştur. Araştırmada, Bursa Nilüfer İlçesi Görükle Mahallesi içerisinde seçilen kafe restoranlarda yapısal konfor koşullarına ilişkin kullanıcı memnuniyetini belirlemek üzere anket çalışması ve mekân analizi yapılmıştır. Araştırmanın amacı; ülkemizdeki kafelerin bulunduğu koşulların, konfor koşullarının değerlendirilmesi gerekliliğini göstermesi üzerine, yapılacak olan araştırma sonucunda elde edilecek sonuç ve öneriler doğrultusunda bir sonraki kafe tasarımına ışık tutmasıdır. Yapılan anket sonuçları, fiziksel çevre kontrolü ve planlama faktörleri adı altında değerlendirilmiştir. Bu değerlendirmeler sonucunda ortaya çıkan memnuniyet ve memnuniyetsizlik sonuçları yorumlanmış ve bu sonuçlar üzerine öneriler sunulmuştur.

Anahtar Kelimeler: Kafe mekânları, Yapısal Konfor, Konfor Koşulları.

\section{Evaluation of Comfort Criterias in the Cafes: Example From Görükle I Bursa}

\begin{abstract}
Cafes are places where people evaluating their free time, relaxing, eating, drinking, talking and socializing. Cafes fulfill various social functions and as a service and cultural institution, they follow the economic and social developments of the time as in the past years and provides new services, serves new requirements. The hypothesis "Ensuring structural comfort in the cafes that people prefer frequently in daily life, providing the user satisfaction to his / her environment in a psychological way and maximizing the physical performance" is explained in this resarch. Survey study and spatial analysis were performed to determine the user satisfaction regarding the structural comfort conditions in the selected café restaurants in Bursa Nilufer District Görükle Neighborhood. The purp ${ }^{1}$ ose of the research is to shed light on the next cafe designs in line by showing the necessity of evaluating the conditions in the cafes in our country with the results and recommendations from the survey.Survey results were evaluated under physical environment controland planning factors. As a result of these evaluations, the results of satisfaction and dissatisfaction are interpreted and recommendations on these results are presented.
\end{abstract}

Keywords: Cafe spaces, Structural comfort, Comfort conditions.

\footnotetext{
${ }^{1}$ Mimar, Uludağ Üniversitesi Yapı Bilgisi Anabilim Dalı, Yüksek Lisans Öğrencisi, Türkiye

${ }^{2}$ Prof. Dr., Uludağ Üniversitesi, Yapı Bilgisi Anabilim Dalı, Mimarlık Bölümü, Türkiye

*ilgili Yazar/ Corresponding Author: ekormen@gmail.com, 05548937983

Gönderim Tarihi: 02.05.2019

Kabul Tarihi: 29.06.2019
} 


\section{GíRiş}

Kafeler insanların günlük hayatlarında, dinlenmek, kitap okumak, müzik dinlemek, sohbet edip bir şeyler yiyip içmek için tercih ettikleri ve sosyalleştikleri mekânlardır. Günümüzde kafe sektörü gelişmiş olmasına rağmen çok sayıda yapısal konfor sorununu içinde barındırmaktadır. Bir işletmecinin kafe mekânı için sağlaması gereken çok sayıda etmen vardır. Bunlar; yiyecek içecek kalitesi, personelin verimliliği, kafe mutfağının hijyen durumu, mekân organizasyonu, ısıl konfor, görsel konfor, işitsel konfor gibi etmenlerdir. Tüm bu etmenler içerisinde geri plana atılan yapısal konfor problemleri olup kullanıcı memnuniyeti düşünülmemektedir. Sosyal hayatta önemli yeri olan bir kafenin her binada olduğu gibi konfor koşullarının maksimum düzeyde sağlanması kullanıcı memnuniyeti açısından oldukça önem arz etmektedir.

Çalışmanın hipotezi "Kafe mekânlarında ki yapısal konfor koşullarının uygulanması, kullanıcıların psikolojik açıdan çevresinden memnunluk duyarak fiziksel performansını üst düzeye çıkarmasını sağlar" olarak ortaya konulmuştur. Konfor koşulları açısından yeterli olmayan kafeler kullanıcı memnuniyetini azaltmakta olup kullanıcıların fiziksel ve psikolojik durumlarını etkilemektedir. Bu konuyla ilgili yapılan literatür araştırmasında kafeler ile ilgili olarak, (Delikara, 2004) İstanbul'da ki kafeler ve kafelerin mekân örgütlenmesi ve kullanılan malzemeler açısından değerlendirilmesi üzerine bir çalışma yapılmıştır. (Celasin, 2009) İşitsel konforla bağlantı kurulabileceği düşünülerek Isparta da canlı müzik sunan kafelere yönelik bir çalışma yapılmıştır. (Ertem, 2016) aydınlanmanı niceliği ve niteliğinin mekân ve insan üzerindeki etkisi ile ilgili bir çalışma yapılmıştır. (Altay, 2014) mekân ambiyansı bağlamında kafe restoran tasarımındaki iç mekân detaylarının kullanıcı algısına olan etkisi üzerine çalışma yapılmıştır. Ayrıca kafe mekânları dışında konfor koşulları ile kullanıcı psikolojisi üzerine çalışmalar yapıldığı görülmüştür. Örneğin; (Manav, Küçükdoğdu,2006), aydınlık düzeyi ve renk sıcaklığının performansa etkisi üzerine, ofislerde konfor koşulları sağlandığı takdirde üretim ve performansın arttığına dair, psikolojik konfor koşullarını araştırmak üzere 4 farklı aydınlık düzeyi ve üç farklı renk sıcaklığı ile sekiz farklı aydınlatma senaryosu oluşturularak bir çalışma yapılmıştır. (Özil, 2008), hasta yatak odalarında görsel konfor koşullarının örneklerle incelenmesi çalışması yapılarak hastanelerde görsel konfor koşulları ve hasta psikolojisi ilişkisinden bahsedilmiştir. (Al, 2014), eğitim yapılarında fiziksel konfor koşullarının öğrenci başarısına etkisi incelenmiştir. (Özdamar, Umaroğulları 2017), bir ofis yapısı örneğinde iç hava kalitesi ve ısıl konfor koşullarının çalışanların iş verimini ne yönde etkilediği konusunda araştırma yapılmıştır. (Ş.Sezer, 2015), bir eğitim binası üzerinde kullanıcı memnuniyetinin konfor koşulları açısından değerlendirmesi yapılmıştır.

Sonuç olarak, bina içinde konfor koşullarının sağlanması insanların çevresinden psikolojik açıdan memnuniyet duyması demektir. Bu durum insanların fiziksel performansının üst düzeye çıkmasında etkilidir. Bu durum; kafelerde olduğu gibi tüm yapılarda görsel, iklimsel, işitsel ve gereken her türlü konfor koşulunun en üst düzeyde sağlanmasını zorunlu kılmaktadır. Ülkemizde kafelerin bulunduğu koşullar konfor koşullarının değerlendirilmesi gerekliliğini göstermektedir. Bu gelişmelere ışık tutması açısından kafeler ve kullanıcı tercihleri üzerine bir çalışma yapılmak istenmiştir. Bu araştırma ve sonuçlarından çıkarılacak bilgilerin hedefi; Bursa Nilüfer İlçesi Görükle Mahallesi içinde seçilen kafelerin yapısal konfor açısından uygun olup olmadığının belirlemesidir. Elde edilecek sonuçlar ile yeni bir kafe tasarımının nasıl olabileceğine dair kazanımlar sağlanacaktır. Kullanıcıların kafe mekânlarındaki fiziksel çevre kontrolü ve planlama faktörleri adı altında görsel, işitsel, ergonomik ve ısıl konfor şartlarının değerlendirilmesi için anket çalışması yapılacaktır. Kullanıcıların kafelerdeki ortamı değerlendirmeleri ve beklentilerini belirlemeye yönelik bu araştırma için uygulanacak 
olan anketlerdeki memnuniyet ve istekler istatiksel yöntemlerle değerlendirilecektir. Alınan cevaplara göre mevcut kafelerin konfor şartları ve kullanıcı memnuniyetleri kıyaslanacaktır.

\section{KAFE MEKÂNLARININ TANIMI, TARIHÇESI VE TÜRLERI}

Kafeler insanların boş zamanlarını değerlendirip, dinlendikleri, bir şeyler yiyip içerek sosyalleştikleri mekânlar olarak tanımlanabilir. "Kahve" sözcüğünün Etiyopya'nın bir bölgesi olan Kaffa'dan geldiği ya da insana zindelik vermesinden dolayı güç veya kudret anlamına gelen "kuvve" sözcüğünden geldiği öngörülmektedir (Delikara, 2004). Sınırlı bir menüsü olan ve içki ve yemek servisinin de yapılabildiği kafelerin temeli kahvehanelere dayanmaktadır (Kolektif, 2004).

Kahveyi uzun bir süre sadece Arapların kullandığı bilinmektedir. Kahvenin ana memleketi Yemen, Moka dolaylarıdır. 15. ve 16. yüzyıllar arasında tüm dünyaya yayılmıştır. İstanbul'a ise Kanuni Sultan Süleyman devrinde Özdemir Paşa tarafından Afrika'dan getirilmiş ve kısa zamanda halk arasında yaygınlaşmıştır.1554 yılında İstanbul'da ilk kahvehane Şam'lı ve Halep'li iki kişi tarafından açılmıştır. Osmanlı İmparatorluğunda kahvehaneler halkın toplanıp, padişahı ve yönetimi eleştirdiği ve taleplerini dile getirdiği yerler olmaya başlayınca kahve 17. Yüzyılda Osmanlı tarafından "kahve içiminin şeriata uygun olmadığı" gerekçesi ile yasaklanmıştır. Yasaklanmasına rağmen toplumsal bir mekân haline gelen kahvehaneler varlıklarını sürdürmüştür. Başlangıçta kahvehaneler bir tüketim yeriyken zamanla sohbet, dinlenme, eğlenme mekânlarına dönüşmüştür ve 19. Yüzyılın başlarından itibaren kahve dışında başka içecek ve yiyeceklerin servis edildiği mekânlar haline evrilmiştir.

20. yüzyılda cinsiyet ayrımı ortadan kalkarak kahvehane ve pastanelere kadınlar kabul edilmeye başlamıştır. Halk için büyük bir yenilik olan kafeteryalara kadınlar ve gençler gitmeye başlamıştır (Resim 1).

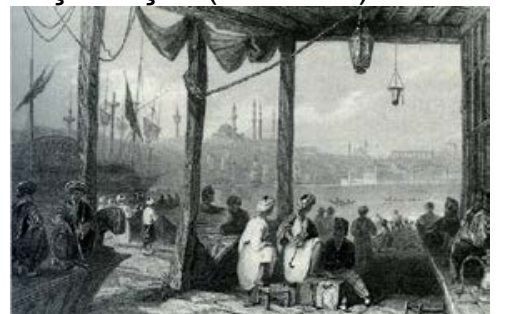

İstanbul Limanı'nda bir kahvehane, 1839

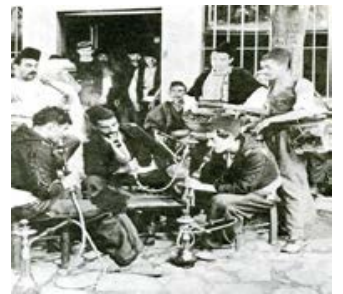

19. yüzyıl sonlarında bir Türk kahvehanesi Resim 1. 19. Yüzyıl Türk kahvehaneleri (Hattox, 1988).

Kahvehanecilik sektörü, yıllar içerisinde farklı kahvehane tipleri olarak dönüşüme uğramıştır. Kahvehanelerin birbirinden farklı hizmetler veren (sokak tezgâhından lüks kafeye kadar) mekânlara dönüşmüştür. Kafeler dönemin ekonomik ve toplumsal gelişmelerini takip ederek her on yılda bir dönüşüm geçirmektedir. Oluşan rekabet ile birlikte sayıları her geçen gün artan kafeler, menü ve iç mekân özellikleri ile çeşitlenmiştir. Zaman içerisinde yeni kafe türleri oluşmuştur. Kahvenin yanında farklı yeme-içme alternatiflerine sahip kafeler olduğu gibi içecek olarak yalnızca kahvenin sunulduğu kafeler de vardır. Heise kafe türlerini aşağıdaki gibi ayırmıştır (Resim 2); Kafe Restoranlar; alkollü ya da alkolsüz içecek servisi ile birlikte yemek servisinin de yapıldığı kafelerdir. Fransa'da 1800'den sonra restoranların ortaya çıkmasıyla beraber, sık sık kahvehanelerle restoranların bileşimi olan yerler açılmaya başladı. Viyanalı kahvehaneciler sektörde varlıklarını devam ettirebilmek adına, 1811-1813 yılları arasında kıta ablukası yüzünden çekirdek kahve bulunamadığı için 1811 yılından itibaren günde iki kez sıcak yemek servisi yapmaya başladılar. 
-Kafe Pastaneler; alkolsüz içecek servisi ile birlikte tatlı ve pasta servisinin de yapıldığı kafelerdir. Avrupa'da 1813'de kıta ablukasının kaldırılmasından sonra, şekerlemeciler ve pastacılar kahvehane açmaya başladılar. Böylece kafe-pastane türü oluştu ve Avrupa'daki kahvehane türlerinin en önemli parçası oldu.

-Otel Kafeleri; otelciliğin gelişmesi ile ortaya çıkan, özellikli müşteri hizmeti biçimlerinin farklılaşması ve uluslararası kültür alışverişinin artması ile gelişimini hızlandıran bir kafe türüdür. Bu kafe türü 18. yüzyıldaki İngiliz otellerinin "coffee-rom"undan, 1900 civarında dünyanın tüm büyük şehirlerinde karşılaşılabilecek kolonial ya da kontinental stildeki görkemli otel-kafe restoranlarına kadar uzanmaktadır (Araz, 2007).

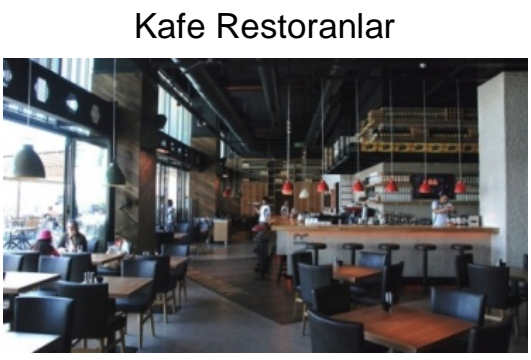

Mid-point Kafe Restoran

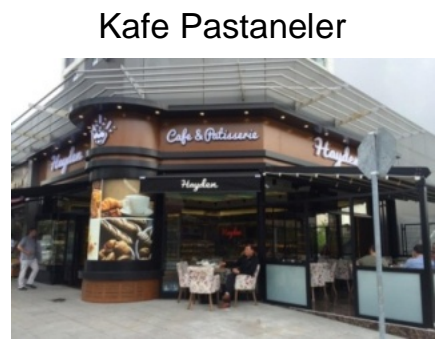

Hayden Kafe Pastane
Otel Kafeleri

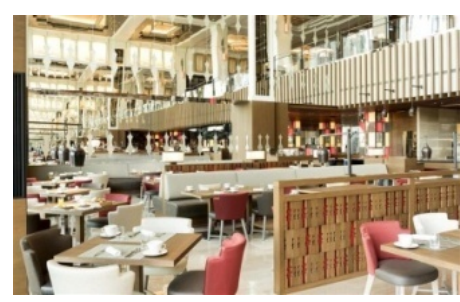

Swiss Otel Kafe

Resim 2. Kafe türleri ve Türkiye'den örnekler (www.fortuneturkey.com, www.haydencafepastane.com, www.swissotel.com.tr)

\section{ALAN ÇALIŞMASI}

Alan çalışması için seçilen bölge, Bursa Uludağ Üniversitesi Görükle Kampüsü'nün hemen girişinde bulunan Nilüfer İlçesi Görükle Mahallesi içerisinde seçilen kafelerden oluşmaktadır. Kafe türlerinden olan "Kafe-Restoran" türünden beş kafe seçilmiş ve her kafede kafe sahipleriyle görüşülmüş ve mekân analizleri yapılmıştır (Şekil 1). Anket çalışması, Örnek 1: Kırıntı Kafe-Restoran, Örnek 2: Buda Kafe-Restoran, Örnek 3: Pia Kafe-Restoran, Örnek 4: Baykuş Kafe-Restoran ve Örnek 5: In Patio KafeRestoranlarda uygulanmıştır (Resim 3).

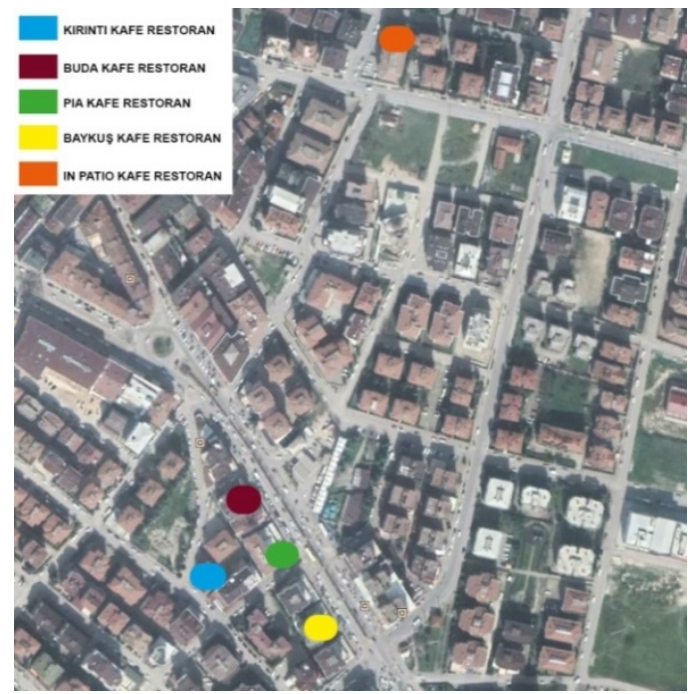

Şekil 1. Görükle Mahallesi, Seçilen Kafe Konumları (www.google.com/maps) 


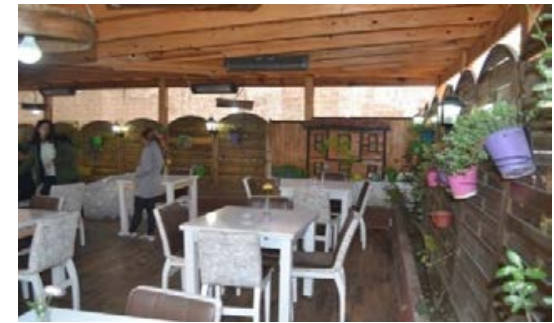

Örnek 1: Kırıntı Kafe Restoran Yarı Açık Alan Görseli

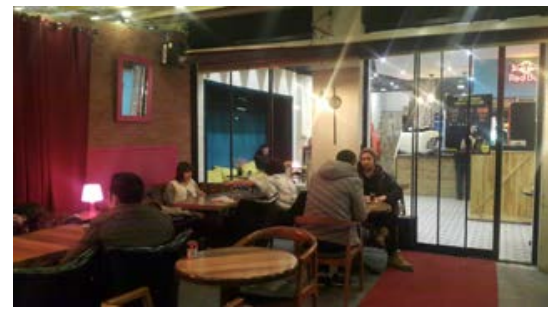

Örnek 2: Buda Kafe Restoran Yarı Açık Alan Görseli

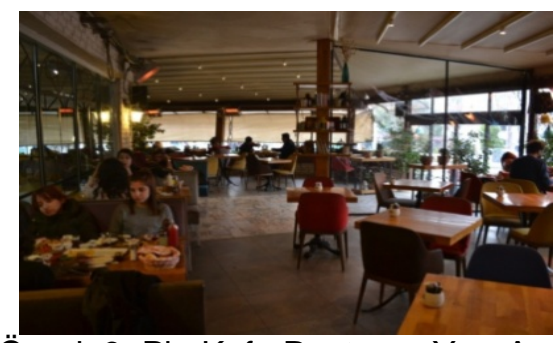

Örnek 3: Pia Kafe Restoran Yarı Açık Alan Görseli

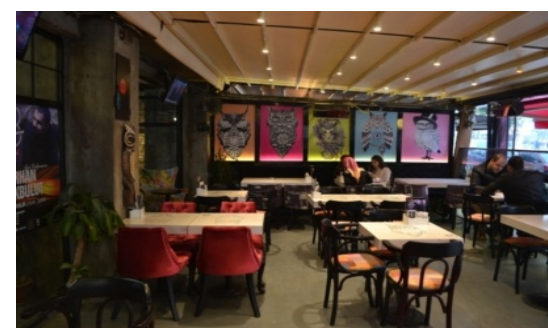

Örnek 4: Baykuş Kafe Restoran Yarı Açık Alan Görseli

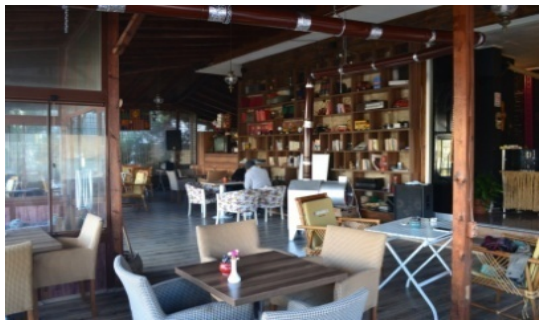

Örnek 5: In Patio Kafe Restoran Yarı Açık Alan Görseli

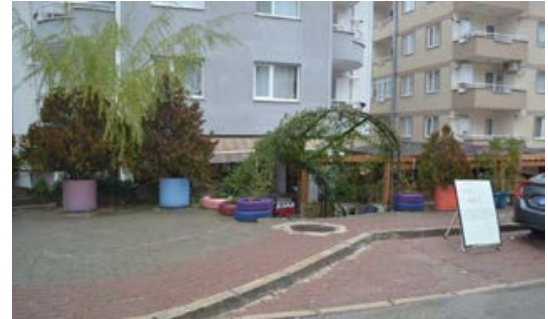

Örnek 1: Kırıntı Kafe Restoran Giriş Görseli

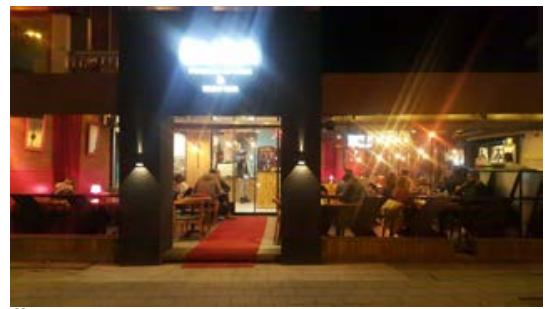

Örnek 2: Buda Kafe Restoran Giriş Görseli

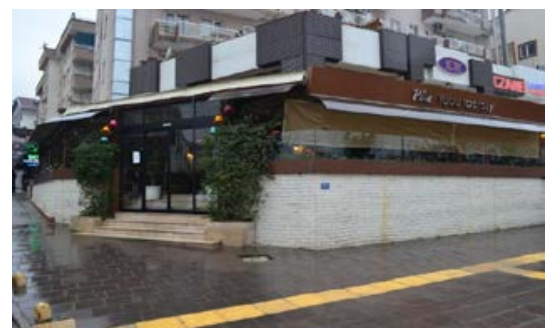

Örnek 3: Pia Kafe Restoran Giriş Görseli

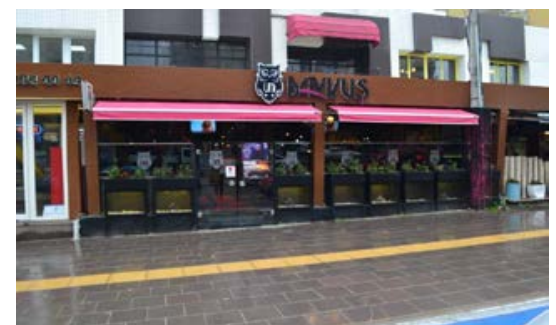

Örnek 4: Baykuş Kafe Restoran Giriş Görseli

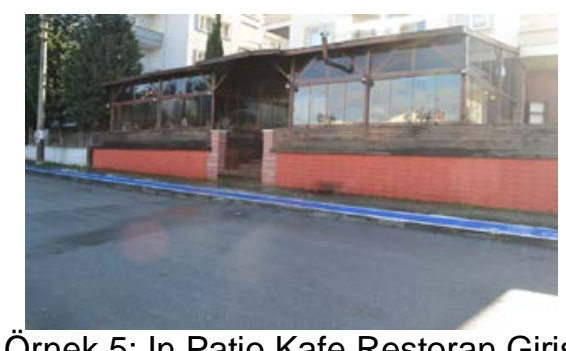

Örnek 5: In Patio Kafe Restoran Giriş Görseli

Resim 3. Alan çalışması için seçilen kafeler (Fot. Eme Güven) 
Örnek 1: Kırıntı Kafe Restoran oldukça sessiz sakin bir sokak olan Filiz Sokakta yer almaktadır. Kafe 2012 yılında açılmıştır ve yapım sistemi betonarme olan bir apartmanın zemin katında bulunmaktadır. Kafe tek katlıdır ve kapasitesi 70 kişiliktir. Kapalı, açık ve yarı açık mekânları vardır. Yarı açık alanın üst örtüsü ahşap malzemeden yapılmış bir üst örtüdür. Döşeme kaplama malzeme olarak yarı açık alanda ahşap, açık alanda taş örgüsü, kapalı alanda ise laminant ahşap parke döşeme malzemesi kullanılmıştır. Tavan ve duvar kaplaması sıva+boya olarak seçilmiştir. Giriş katında konumlanan tuvaletlerde bir bayan ve bir bay olmak üzere iki adet kabin bulunmaktadır. Mutfağı giriş katında yer almaktadır. Kafe otoparkı bulunmamaktadır.

Örnek 2: Buda Kafe Restoran Görükle Mahallesinin ana aksı olan Atatürk Caddesi üzerinde yer almaktadır. Kafe 2006 yılında açılmıştır ve yapım sistemi betonarme olan bir apartmanın zemin katında bulunmaktadır. Kafe üç katıdır ve kapasitesi 130 kişiliktir. Kapalı ve yarı açık mekânları vardır. Yarı açık alanın üst örtüsü alüminyum kanatlı malzemeden yapılan açılır kapanır uzaktan kumandalı tavan sistemidir. Döşeme kaplama malzemesi olarak yarı açık alanda fayans, kapalı alanda; yine fayans döşeme malzemesi kullanılmıştır. Tavan kaplaması sıva+boya olarak seçilmiştir. Duvar kaplaması olarak fayans, taş cila gibi çeşitli malzemeler kullanılmıştır. Üst katta konumlanan tuvaletlerde bir bayan ve bir bay olmak üzere iki adet kabin bulunmaktadır. Mutfağı giriş katında yer almaktadır. Kafe otoparkı bulunmamaktadır.

Örnek 3: Pia Kafe Restoran Görükle Mahallesinin ana aksı olan Atatürk Caddesi üzerinde yer almaktadır. Kafe 2007 yılında açılmıştır ve yapım sistemi betonarme olan bir apartmanın zemin katında bulunmaktadır. Kafe üç katııdır ve kapasitesi 150 kişiliktir. Kapalı ve yarı açık mekânları vardır. Yarı açık alanın üst örtüsü alüminyum kanatı malzemeden yapılan açılır kapanır uzaktan kumandalı tavan sistemidir. Döşeme kaplama malzemesi olarak yarı açık alanda fayans, kapalı alanda; üst katta laminant ahşap parke, zemin katta ise yine fayans döşeme malzemesi kullanılmıştır. Tavan kaplaması sıva+boya olarak seçilmiştir. Duvar kaplaması olarak sıva+boya, tuğla kaplama ve fayans gibi çeşitli malzemeler kullanılmıştır. Üst katta konumlanan tuvaletlerde iki bayan ve iki bay olmak üzere dört adet kabin bulunmaktadır. Mutfağı bodrum katta yer almaktadır. Kafe otoparkı bulunmamaktadır.

Örnek 4: Baykuş Kafe Restoran Görükle Mahallesinin ana aksı olan Atatürk Caddesi üzerinde yer almaktadır. Kafe 2014 yılında açılmıştır ve yapım sistemi betonarme olan bir apartmanın zemin katında bulunmaktadır. Kafe iki katlıdır ve kapasitesi 160 kişiliktir. Kapalı ve yarı açık mekânları vardır. Yarı açık alanın üst örtüsü alüminyum kanatı malzemeden yapılan açılır kapanır uzaktan kumandalı tavan sistemidir. Döşeme kaplama malzemesi olarak epoksi ve laminant parke döşeme malzemesi olarak kullanılmıştır. Tavan kaplaması sıva+boya ve dekorasyon olarak çelik malzeme seçilmiştir. Duvar kaplaması olarak sıva+boya ve tuğla kaplama ayrıca dekoratif baykuş karikatürleri kullanılmıştır. Üst katta konumlanan tuvaletlerde bir bayan ve bir bay olmak üzere iki adet kabin bulunmaktadır. Mutfağı giriş katta yer almaktadır. Kafe otoparkı bulunmamaktadır.

Örnek 5: In Patio Kafe Restoran Görükle Mahallesinin yan aksı olan ve sakin sessiz bir cadde olan Bahriye Üçok Caddesi üzerinde yer almaktadır. Kafe 2013 yılında açılmıştır ve yapım sistemi betonarme olan bir apartmanın zemin katında bulunmaktadır. Kafe tek katıdır ve kapasitesi 80 kişiliktir. Kapalı, yarı açık ve açık mekânları vardır. Yarı açık alanın üst örtüsü ahşap strüktürel sistemdir. Döşeme kaplama malzemesi olarak yarı açık alanda laminant parke döşeme malzemesi ve kapalı alanda fayans kullanılmıştır. Tavan kaplama malzemesi kapalı alanda alçıpan sistem ve sıva+boya, yarı açık alanda ise tavan ahşap sistemdir. Duvar kaplaması olarak kapalı alanda 
sıva+boya ve yarı açık alanda ise ahşap sistemdir. Giriş katta konumlanan tuvaletlerde bir bayan ve bir bay olmak üzere iki adet kabin bulunmaktadır. Mutfağı giriş katta yer almaktadır. Kafe otoparkı bulunmamaktadır.

Tablo 1'de kafelerin mekânsal özellikleri birbiri ile karşılaştırmalı olarak verilmiştir.

Tablo 1. Kafelerin Mekansal Özellikleri

\begin{tabular}{|c|c|c|c|c|c|}
\hline Kafeler: & Örnek 1 & Örnek 2 & Örnek 3 & Örnek 4 & Örnek 5 \\
\hline Yapım Tarihi & 2012 & 2006 & 2007 & 2014 & 2013 \\
\hline Yapım Sistemi & Betonarme & Betonarme & Betonarme & Betonarme & Betonarme \\
\hline Konumu & $\begin{array}{l}\text { Apartman } \\
\text { Zemin katı }\end{array}$ & $\begin{array}{l}\text { Apartman Zemin } \\
\text { katı }\end{array}$ & $\begin{array}{l}\text { Apartman Zemin } \\
\text { katı }\end{array}$ & $\begin{array}{l}\text { Apartman } \\
\text { Zemin katı }\end{array}$ & $\begin{array}{l}\text { Apartman } \\
\text { Zemin katı }\end{array}$ \\
\hline Kat Sayısı & 1 Katlı & 3 Katlı & 3 Katlı & 2 Katlı & 1 Katlı \\
\hline Kişi Kapasitesi & 70 & 130 & 150 & 160 & 80 \\
\hline $\begin{array}{l}\text { Döşeme Kaplama } \\
\text { Malzemesi (Sırayla, } \\
\text { Kapalı Alan, Yarı } \\
\text { açık alan, Açık } \\
\text { Alan, }\end{array}$ & $\begin{array}{l}\text { Laminant, } \\
\text { ahşap kaplama, } \\
\text { Taş örgü }\end{array}$ & $\begin{array}{l}\text { Fayans, Fayans } \\
\text { Döşeme } \\
\text { Malzemesi, Açık } \\
\text { alan yoktur. }\end{array}$ & $\begin{array}{l}\text { Laminant, Fayans } \\
\text { Döşeme } \\
\text { Malzemesi, Açık } \\
\text { alan yoktur. }\end{array}$ & $\begin{array}{l}\text { Laminant, } \\
\text { Laminant } \\
\text { Döşeme } \\
\text { Malzemesi, } \\
\text { Açık alan } \\
\text { yoktur. }\end{array}$ & $\begin{array}{l}\text { Fayans, } \\
\text { Laminant } \\
\text { Döşeme } \\
\text { Malzemesi, } \\
\text { Açık alan } \\
\text { yoktur. }\end{array}$ \\
\hline $\begin{array}{l}\text { Yarı Açık Alan Üst } \\
\text { Örtü Malzemesi }\end{array}$ & $\begin{array}{l}\text { Ahşap Malzeme } \\
\text { Üst Örtü }\end{array}$ & $\begin{array}{l}\text { Alüminyum açılır } \\
\text { kapanır üst örtü } \\
\text { sistemi }\end{array}$ & $\begin{array}{l}\text { Alüminyum açılır } \\
\text { kapanır üst örtü } \\
\text { sistemi }\end{array}$ & $\begin{array}{l}\text { Alüminyum } \\
\text { açlır kapanır } \\
\text { üst örtü sistemi }\end{array}$ & $\begin{array}{l}\text { Ahşap } \\
\text { Malzeme Üst } \\
\text { Örtü }\end{array}$ \\
\hline Tavan Kaplaması & Sıva+Boya & Siva+Boya & Siva+Boya & $\begin{array}{l}\text { Sıva+Boya, } \\
\text { Çelik }\end{array}$ & $\begin{array}{l}\text { Sıva+Boya, } \\
\text { Ahşap } \\
\text { Kaplama }\end{array}$ \\
\hline Duvar Kaplaması & Siva+Boya & $\begin{array}{l}\text { Fayans, taş cila } \\
\text { gibi çeşitli } \\
\text { malzemeler }\end{array}$ & $\begin{array}{l}\text { Sıva+Boya, Fayans } \\
\text { gibi çeşitli } \\
\text { malzemeler }\end{array}$ & $\begin{array}{l}\text { Sıva+Boya, } \\
\text { Tuğla gibi çeşitli } \\
\text { malzemeler }\end{array}$ & $\begin{array}{l}\text { Sıva+Boya, } \\
\text { Yarı Açık } \\
\text { Alanda Ahşap } \\
\text { Kaplama }\end{array}$ \\
\hline Mutfak Konumu & Giriş Katı & Giriş Katı & Giriş Katı & Giriş Katı & Giriş Katı \\
\hline Tuvalet Konumu & Giriş Katı & Birinci Kat & Birinci Kat & Birinci Kat & Giriş Katı \\
\hline Otopark Durumu & Yok & Yok & Yok & Yok & Yok \\
\hline
\end{tabular}

Anketlerin araştırmanın kapsamını temsil edeceği varsayılarak her kafede 40 kullanıcıya anket soruları yöneltilmiştir. Kullanıcılara 3 adet demografik soru, 3 adet görüş bildirimi, 29 adet memnuniyet sorusu yöneltilmiş ve verilen cevaplar grafiklere dökülerek değerlendirilip yorumlanmıştır. Anket içeriğinde planlama ve fiziksel çevre kontrolü olarak iki ana başlıkta sorular oluşturulmuştur (Şekil 2, Şekil 3).

\section{PLANLAMA}
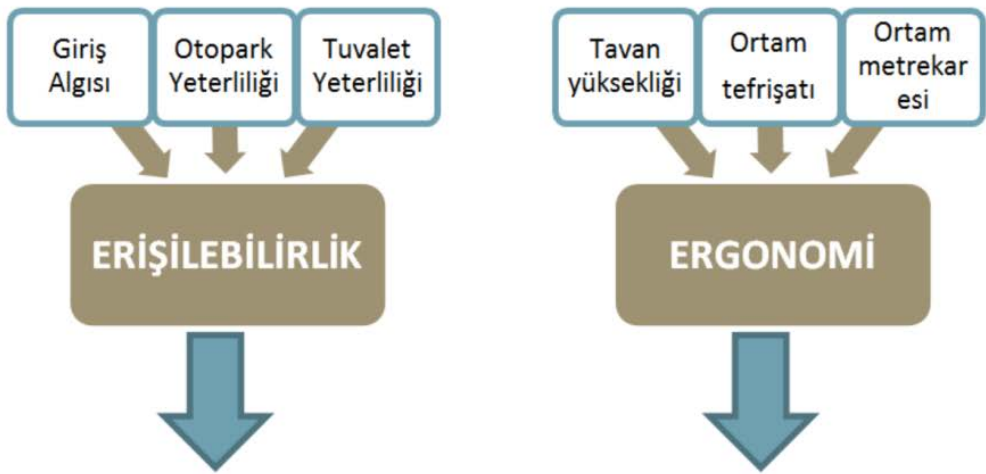

\section{KULLANICILARIN PLANLAMADA DEĞERLENDIRDIKLERi} KONFOR KOŞULLARI

Şekil 2. Konfor koşulları ve konfor koşulları açısından değerlendirilecek mimari tasarım parametresi olarak 'planlama' 


\section{FiZIKSEL ÇEVRE KONTROLÜ}

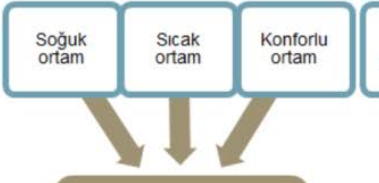

ISIL KONFOR

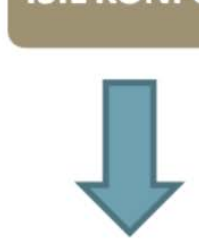

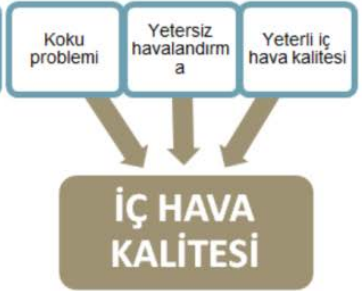

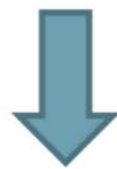

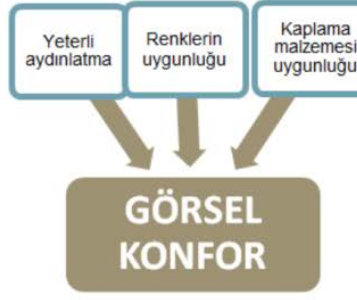

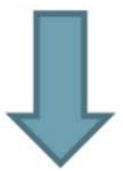

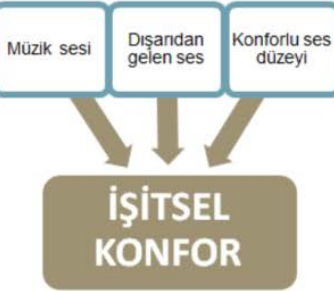

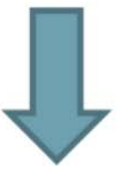

\section{KULLANICILARIN FiZiKSEL IÇ ÇEVRE KALITESININ ÖLçÜMÜNDE DEǦERLENDIRDiKLERi KONFOR KOŞULLARI}

Şekil 3. Konfor koşulları ve konfor koşulları açısından değerlendirilecek mimari tasarım parametresi olarak 'fiziksel çevre kontrolü'

\section{DEĞERLENDIRME}

Anket çalışması sonucu elde edilen sonuçlar grafiksel olarak verilmiş, literatürden elde edilen bilgiler ışığında derlenerek değerlendirilmiştir. Ankette; demografik sorular cinsiyet, yaş aralığı ve eğitim durumu üzerine oluşturulmuştur (Tablo 2). Planlama, insanların yaşamlarını hem fiziksel hem de psikolojik olarak rahat ve sağlıklı bir biçimde devam ettirmeleri için alınması gereken önlemlerini kapsar. Fiziksel çevre kontrolü, insanların yaşadıkları mekânın tasarımı yapılırken konfor koşullarını sağlayacak olan faktörlerin göz önünde bulundurulmasını gerçekleştiren bir inceleme ve değerlendirme sistemidir. Anket başlıkları planlama ve fiziksel çevre kontrolü parametreleri altında oluşturulmuştur. Planlama parametresi, erişilebilirlik ve ergonomi alt başlıklarından oluşmuştur. Anket sonuçları Grafik 1 ve 2 de gösterilmiştir.

Tablo 2. Demografik değerler

\begin{tabular}{lccccc} 
Kafeler: & Örnek 1 & Örnek 2 & Örnek 3 & Örnek 4 & Örnek 5 \\
\hline Cinsiyet: & & & & & \\
\hline Kadın & 21 & 22 & 18 & 17 & 22 \\
Erkek & 19 & 18 & 22 & 23 & 18 \\
Yaş: & & & & & \\
\hline 18 ve altı & 0 & 1 & 0 & 3 & 2 \\
19-25 yaş arası & 25 & 25 & 25 & 22 & 20 \\
26-45 yaş arası & 9 & 11 & 11 & 13 & 12 \\
46-65 yaş arası & 6 & 3 & 4 & 2 & 6 \\
65 ve üst & 0 & 0 & 0 & 0 & 0 \\
Eğitim durumu: & & & & & \\
\hline Illkokul & 0 & 2 & 0 & 2 & 1 \\
Ortaokul & 0 & 0 & 0 & 0 & 0 \\
Lise & 3 & 6 & 5 & 4 & 5 \\
Üniversite & 30 & 28 & 33 & 30 & 32 \\
Lisanüstü & 6 & 4 & 2 & 4 & 2 \\
\hline
\end{tabular}



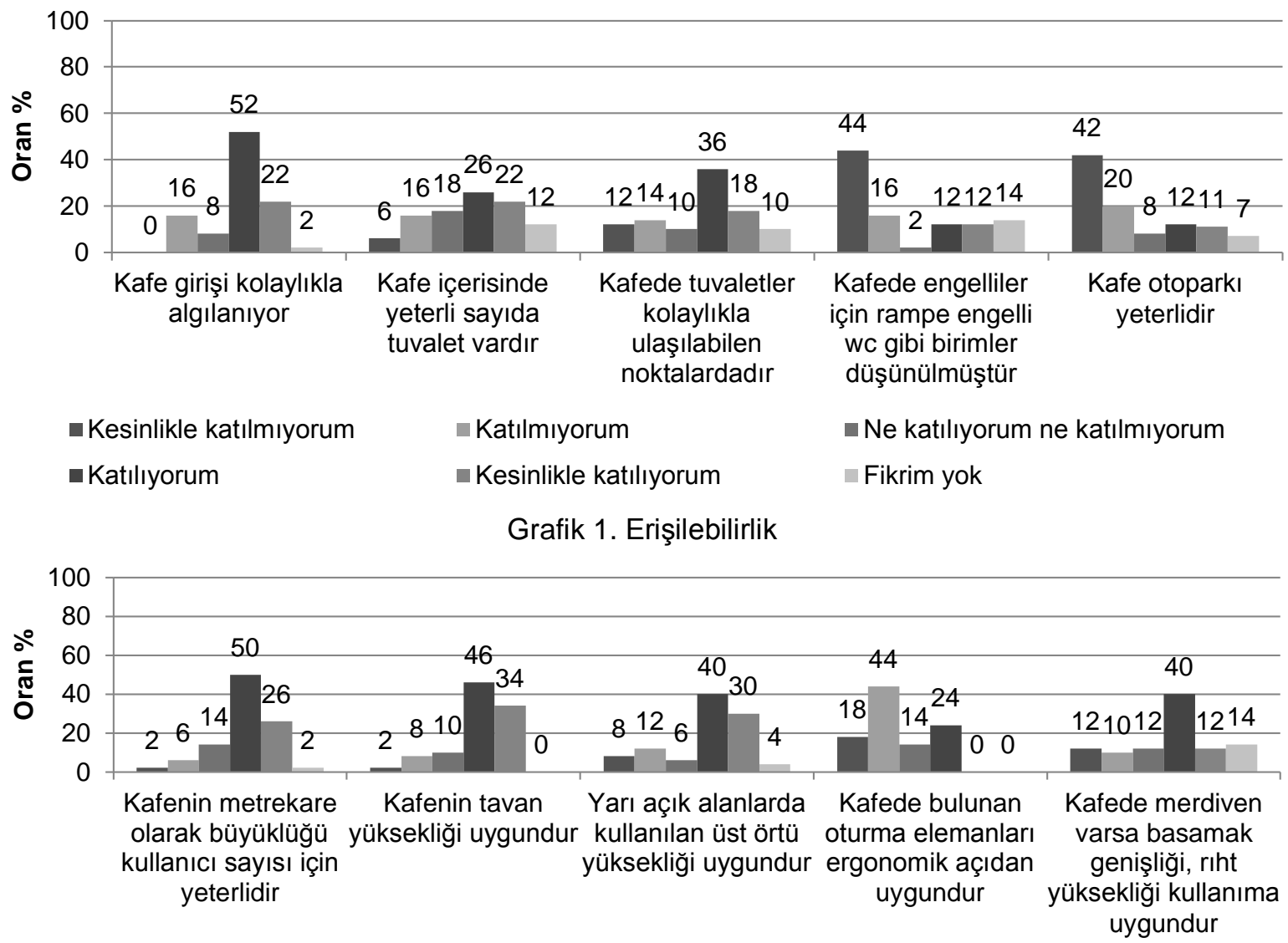

- Kesinlikle katılmıyorum

- Katılıyorum

\author{
Katılmıyorum \\ - Kesinlikle katılıyorum
}

- Ne katılıyorum ne katılmıyorum

$\square$ Fikrim yok

Grafik 2. Ergonomi

Fiziksel çevre kontrolü parametresi, ısıl konfor, işitsel konfor, görsel konfor ve iç hava kalitesi alt başlıklarından oluşmuştur. Anket sonuçları Grafik 3, 4, 5 ve 6'da gösterilmiştir.

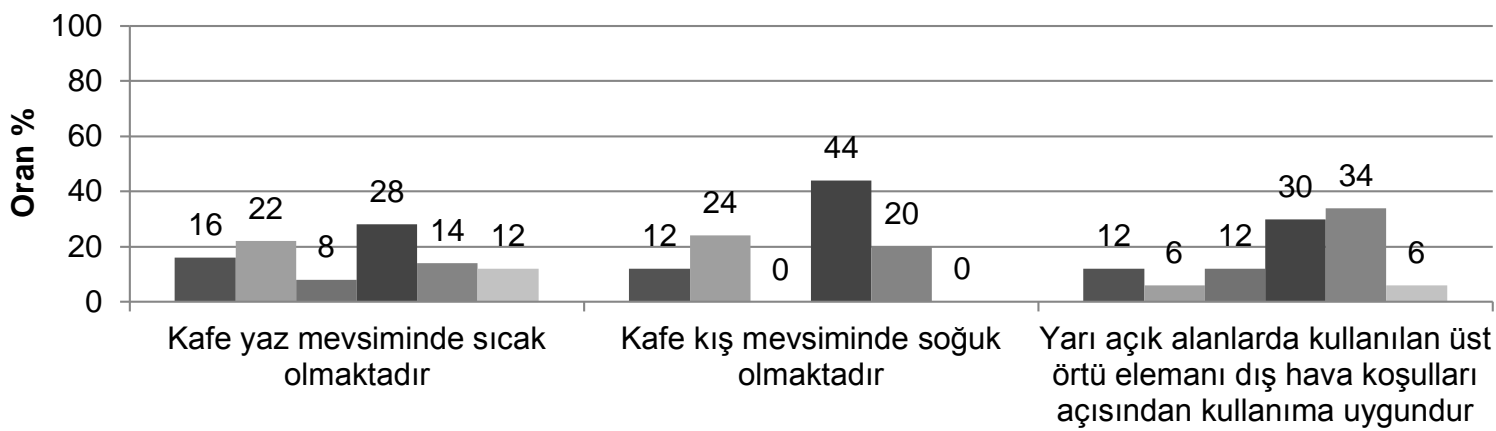

$\begin{array}{ll}\square \text { Kesinlikle katılmıyorum } & \square \text { Katılmıyorum } \\ \square \text { Katılıyorum } & \square \text { Kesinlikle katılıyorum }\end{array}$

Grafik 3. Isıl Konfor
- Ne katılıyorum ne katılmıyorum

- Fikrim yok 
Kafelerde Kullanıcı Memnuniyetinin Konfor Koşulları Açısından Değerlendirilmesi: Görükle/Bursa Örneği Evaluation of Comfort Criterias in the Cafes: Example From Görükle / Bursa

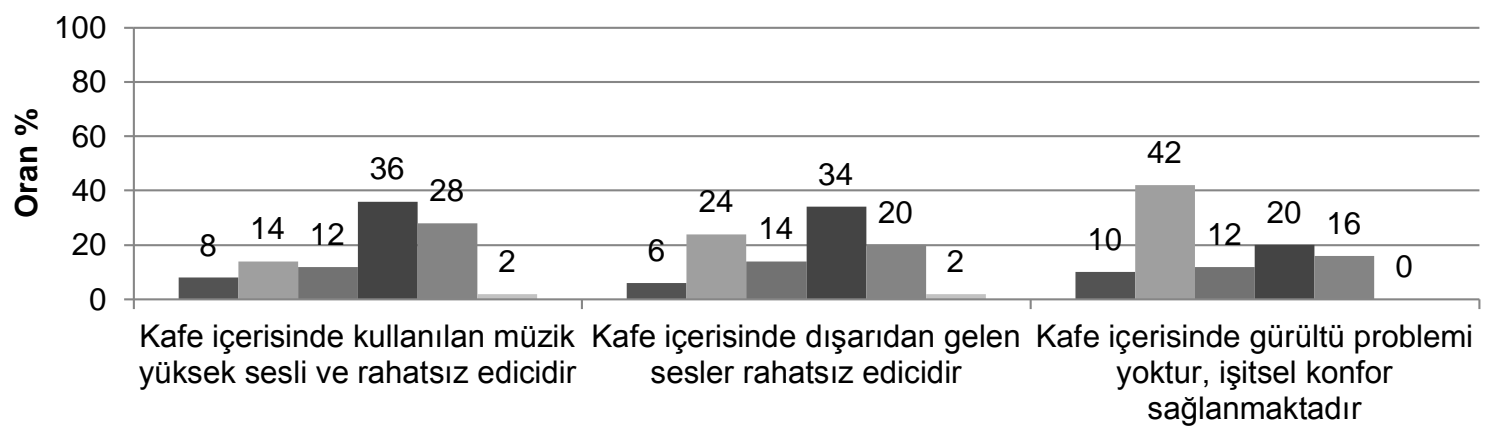
- Kesinlikle katılmıyorum
Katılmıyorum
- Ne katılıyorum ne katılmıyorum
- Katılıyorum
Kesinlikle katılıyorum
Fikrim yok
Grafik 4. İşitsel Konfor

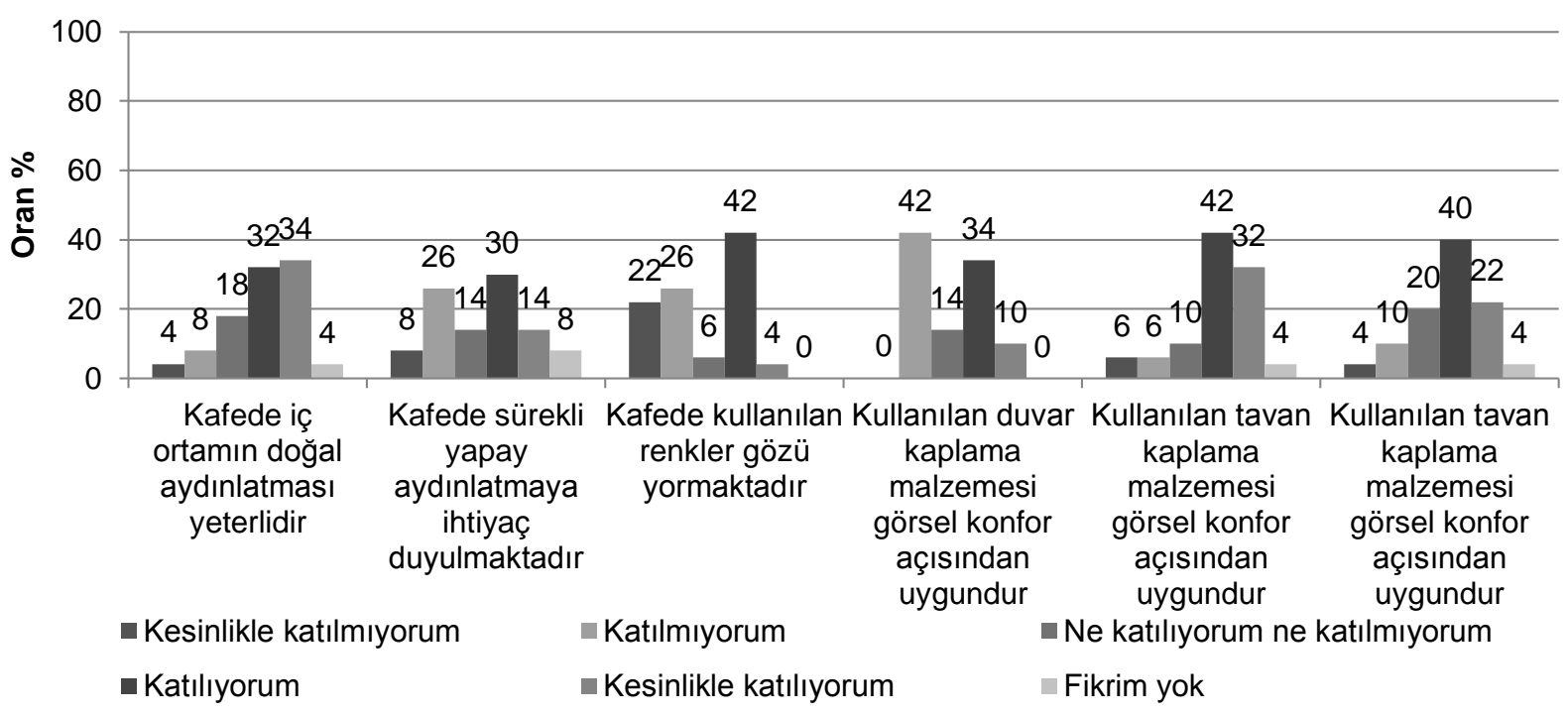

Grafik 5. Görsel Konfor

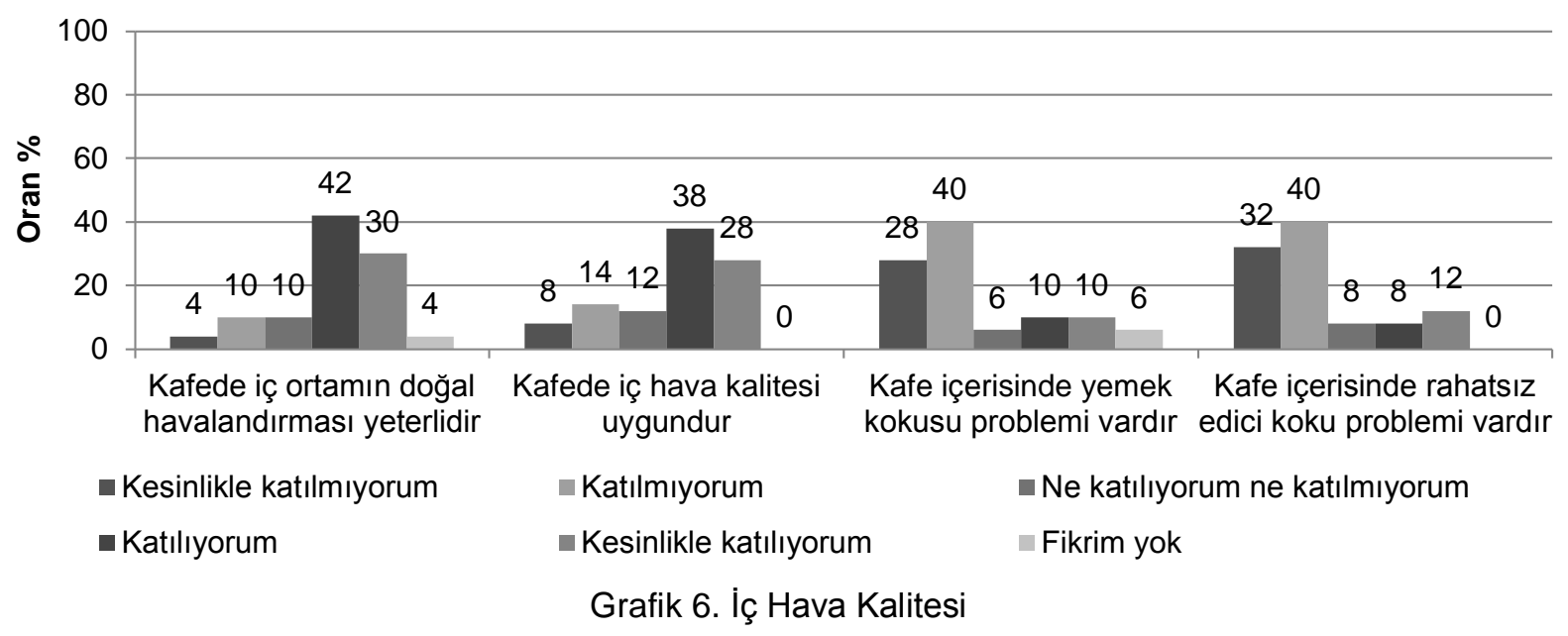

Yapılan araştırma kapsamında, kafelerde vakit geçiren kullanıcıların memnuniyet veya memnuniyetsizlik duydukları konuların belirlenmesi, yeni tasarlanacak kafelerin tasarım verilerinin oluşturulması açısından önemlidir. Kesinlikle katılıyorum: +2, Katılıyorum: +1 , Ne katılıyorum ne katılmıyorum değilim: 0, Katılmıyorum:-1, Kesinlikle 
katılmıyorum: -2, Fikrim yok:0 olarak puanlandırılmıştır. Her cevap için sayısal değerler belirlenmiştir. Kullanıcıların vermiş olduğu her cevap soru bazında değerlendirilmiş ve Tablo 3 'deki değerlere ulaşılmıştır.

Tablo 3. Kullanıcı Memnuniyeti Değerlendirme Verileri

\begin{tabular}{|c|c|c|c|c|c|}
\hline & & & & Kullanıcı & inuniyeti \\
\hline & & Değerlendirme Verileri & Puan & Memnun & $\begin{array}{c}\text { Memnun } \\
\text { değil }\end{array}$ \\
\hline & & Kafenin girişi algısı & +80 & $\sqrt{ }$ & \\
\hline & 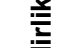 & Kafe içerisinde yeterli sayıda tuvalet durumu & +42 & $\sqrt{ }$ & \\
\hline & $\frac{\overline{0}}{0}$ & Kafede tuvaletler kolaylıkla ulaşılabilen noktalarda olması & +34 & $\sqrt{ }$ & \\
\hline & $\overline{\bar{w}}$ & Engelliler için rampa, engelli wc gibi birimlerin düşünülmesi & -68 & & $\sqrt{ }$ \\
\hline$\sum_{<}$ & & Kafe otoparkı yeterliliği & -84 & & $\sqrt{ }$ \\
\hline$\sum_{\alpha}$ & & Metrekare olarak büyüklüğünün kullanıcı sayısı için yeterliliği & +92 & $\sqrt{ }$ & \\
\hline 5 & $\bar{\varepsilon}$ & Kafe tavan yüksekliğinin uygunluğu & +102 & $\sqrt{ }$ & \\
\hline & 흐 & Yarı açık alanlarda üst örtü yüksekliğinin uygunluğu & +72 & $\sqrt{ }$ & \\
\hline & ธิ & Ortam tefrişatı hareket açısından yoğunluğu & +56 & $\sqrt{ }$ & \\
\hline & & Oturma elemanlarının ergonomik açıdan uygunluğu & +60 & $\sqrt{ }$ & \\
\hline & & Merdivenin basamak genişlikleri, rıht yükseklikleri uygunluğu & +30 & $\sqrt{ }$ & \\
\hline & & Kafenin yaz mevsimindeki ısıl konforu & -4 & & $\sqrt{ }$ \\
\hline & $\overline{\bar{n}} \stackrel{0}{\underline{c}}$ & Kafenin kış mevsimindeki ısıl konforu & -36 & & $\sqrt{ }$ \\
\hline & $\underline{\bar{o}}$ & Yarı açık alanlarda kullanılan üst örtünün uygunluğu & +68 & $\sqrt{ }$ & \\
\hline & & Müzik sesinin işitsel konfor açısından uygunluğu & -42 & & $\sqrt{ }$ \\
\hline & 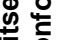 & Dışarıdan gelen seslerin issitsel konfor açısından uygunluğu & -38 & & $\sqrt{ }$ \\
\hline & $\overline{\underline{\theta}}$ & Kafe içerisinde işitsel konfor & -10 & & $\sqrt{ }$ \\
\hline 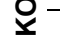 & $\bar{z}$ & Kafede ic ortamın doğal aydınlatma yeterliliği & +84 & $\sqrt{ }$ & \\
\hline$\underset{\sim}{\omega}$ & $\stackrel{\rightleftarrows}{=}$ & Kafe içerisinde yapay aydınlatma intiyacı & +16 & $\sqrt{ }$ & \\
\hline$\stackrel{\rho}{>}$ & $\underline{\bar{g}}$ & Kafede kullanılan renklerin görsel konfor durumu & -20 & & $\sqrt{ }$ \\
\hline Uَّ & $\bar{\Phi}$ & Duvar kaplama malzemesinin görsel konfor durumu & -12 & & $\sqrt{ }$ \\
\hline 1 & : & Tavan kaplama malzemesinin görsel konfor durumu & +88 & $\sqrt{ }$ & \\
\hline 岕 & : & Zemin kaplama malzemesinin görsel konfor durumu & +60 & $\sqrt{ }$ & \\
\hline$\underline{x}$ & & Kafede iç ortamın doğal havalandırmasının yeterliliği & +84 & $\sqrt{ }$ & \\
\hline$\frac{N}{4}$ & $\sum_{\mathbb{J}}^{\infty}$ & Kafe içerisindeki iç hava kalitesinin uygunluğu & +64 & $\sqrt{ }$ & \\
\hline & 蒫 $\frac{5}{\sigma}$ & Kafe içerisindeki yemek kokusu problemi & +66 & $\sqrt{ }$ & \\
\hline & & Kafe iccerisinde rahatsız edici koku problemi & +72 & $\sqrt{ }$ & \\
\hline
\end{tabular}

\section{ARAŞTIRMA SONUÇLARI VE ÖNERILER}

Araştırma yapılan kafelerde kullanıcı memnuniyetine ilişkin görüşler tablo 2 de ki değerlendirme verileri doğrultusunda aşağıda sunulmaktadır:

-Erişilebilirlik açısından eksiklikler mevcuttur; Anket sonucunda otopark sorunu ile ilgili -84 gibi oldukça düşük bir puan elde edilmiştir. Araştırma yapılan kafelerin hiçbirinde otopark bulunmamaktadır, bu nedenle kullanıcılar park sorunu yaşamaktadır. -68 puan ile engelliler için rampa ve wc gibi birimlerin düşünülmediği görülmektedir. Araştırma yapılan hiçbir kafede engelli tuvaletleri ve rampa gibi birimler bulunmamaktadır. Kafe giriş algısının +80 puan ile genel bir olumsuz yorumun olmadığı ve tuvalet sayısı +34 puan ile56 ulaşılabilirliği +42 puan ile genel olarak olumsuz bir düşüncenin olmadığı görülmektedir.

-Ergonomik açıdan olumsuz bir düşünceye ulaşılmamıştır; Kullanıcılar genel olarak ortam metrekaresini +92 puan ile kullanım açısından yeterli görmüşlerdir, kapalı ve yarı açık alanlarda tavan yüksekliğini +102 puan ile yeterli bulup, merdiven basamak genişliği ve rıht yüksekliğini +30 puan ile uygun bulmuşlardır. Ayrıca ortam tefrişatını +60 puan ile ergonomik açıdan rahatsız edici bulmamışlardır.

-Isıl konfor koşulları yaz ve kış mevsimlerinde sağlanamamaktadır; Yapılan anketlere göre kullanıcıların yazın yeterli serinlik değerini -4 puan ile ve kışın yeterli 
sıcaklık değerini -36 puan ile kafelerde bulamadıkları görülmüştür. İnsanların fiziksel performanslarını bulundukları ortamın sıcaklığı büyük oranda etkilemektedir. Ortamın ısıl şartları insanların bedensel ve zihinsel üretim hızını etkilemektedir. Yazın sıcaklardan etkilenmemek için hemen hemen her kafede klima sistemi bulunmaktadır. Binalarda ısıl konfor amaçlı enerji tüketimi yaz ve kış ayları için ayrı ayrı değerlendirmeli ve bu durum dikkate alınmalıdır. Yarı açık alanlarda kullanılan üst örtünün uygunluğu kullanıcılar tarafından +68 puan ile olumlu bulunduğu görülmektedir.

-İşitsel konfor koşulları konusunda bir memnuniyetsizlik durumu görülmektedir; Dışarıdan gelen seslerin rahatsız edici olduğu -38 puan ile, kafe iç mekânında müzik sesinin yüksek olmasından kaynaklı bir gürültü probleminin olduğu -42 puan ile ve bu nedenlerle -10 puan ile işitsel konforun sağlanmadığı görülmektedir. İşitsel konfor, ortamda ses olaylarının rahatsızlık verecek düzeyde olmaması ile sağlanır. Bunun sağlanmasında dış çevreden gelen seslerin iç ortama girmesinin engellenmesi gerekir. Mekânın dış çevreden gelen gürültüden etkilenilmemesinin en kolay çözümü yapı konumunun gürültü kaynağından uzak şekilde seçilmesidir. Bu mümkün değilse, gürültüyü engelleyen peyzaj düzenlemeleri ve mekân organizasyonunda gürültü yönünde tampon bölgeler oluşturulabilir. Yapı tasarımında ise gürültüyü engelleyen (özellikle taş yığma duvar, kerpiç yığma duvar gibi) ağır yapı elemanları tercih edilebilir. Pencere ve kapı açıklıklarının konumunun belirlenmesinde gürültü bir tasarım prensibi olarak ele alınabilir. İç kaplama malzemeleri ise mekânda oluşan sesleri yansıtmamalıdır, yankıyı önleyecek malzeme seçimi yapıımalıdır. Bu çözüm yolları ile işitsel konfor sağlanabilir.

-Görsel konfor koşulları açısından eksiklikler vardır; -20 puan ile kafede kullanılan renklerin gözü yormakta olduğu ve -12 puan ile duvar kaplama malzemelerinin görsel konfor açısından uygun olmadığı görülmektedir. Bunun dışında doğal aydınlatma konusunda -84 puan elde edilerek herhangi bir olumsuz sonuca varılmazken, tavan ve zemin kaplama malzemeleri ortalama +74 puan ile görsel konfor açısından uygun bulunmuştur. Iyileştirilmiş bir ışıklandırma; görsel konforu artırır, gözdeki aşırı yorgunluğu azaltır ve görsel görevler üzerindeki performansı yükseltir. Görsel konfor koşullarının sağlanması için; duvar, tavan ve zemin kaplama malzemeleri gözü yormayacak renk ve dokuda seçilmelidir.

-İç hava kalitesi açısından olumsuz bir düşünceye ulaşılmamıştır; Ortalama +71 puan elde edilerek kullanıcılar tarafından kafe içerisinde doğal havalandırmanın yeterli olduğunu, yemek kokusu probleminin olmadığını ve iç hava kalitesinin sağlandığını düşündüğü görülmektedir.

Bundan sonra tasarlanacak olan kafelerin, mevcut duruma göre memnuniyetsizlik oluşturan verilerinin iyileştirilerek tasarlanması kullanıcıların kafelerde hem fiziksel hem de psikolojik olarak rahat ve sağlıklı bir ortamda vakit geçirmelerini sağlayacaktır. Kafe sahipleri, kullanıcı memnuniyetlerini göz önüne alarak iklimsel, işitsel ve görsel konfor koşullarının sağlanamadığı veya tasarım problemlerinin olduğu durumlarda bu problemleri ortadan kaldırmak amacı ile bir çözüm yoluna gitmelilerdir. 


\section{KAYNAKLAR}

Ertem, Fatmanur, Aydınlanmanın Niceliği - Niteliği Üzerine: Bilişim Çağında Yeni Çalışma Mekânları Haline Gelen Kafelerde Aydınlatma Kalitesi, Yüksek Lisans Tezi, T.C. Beykent Üniversitesi, Fen Bilimleri Enstitüsü Mimarlık Anabilim Dalı, Mimarlık Bilim Dalı, İstanbul 2016.

Sahbaz, Selin, Geçmişten Günümüze Kahvehaneler, Kahvehanelerin Sosyal Yasamdaki Yeri Ve Önemi: Aydın Merkez Örneği, Yüksek Lisans Tezi, T.C. Adnan Menderes Üniversitesi Sosyal Bilimler Enstitüsü, Aydın 2007.

Yavuz Delikara, Şelmin, İstanbul Kafelerinden Örnekler Üzerine Bir Çalışma, Yüksek Lisans Tezi, T.C Yeditepe Üniversitesi Sosyal Bilimler Enstitüsü, İstanbul 2004.

Araz, Aylin, Kafelerde Mekân Örgütlenmesi: Trabzon Örneği, Yüksek Lisans Tezi, Karadeniz Teknik Üniversitesi, Fen bilimleri Enstitüsü, İç mimarlık Anabilim Dalı, Trabzon 2004.

S.G. Abusamhadana, Mohammed, Mevcut Okul Yapılarında Kullanıcı Isıl Konfor Gereksinimleri Bağlamında Enerji lyileştirme Stratejileri: İzmit Ulugazi Ilköğretim Okul Örneği Üzerinden Bir Inceleme, T.C. Kocaeli Üniversitesi, Yüksek Lisans Tezi, Kocaeli 2017.

Utku, Tuğçe, Kafeye Dönüşmüş Apartmanlarda Kullanıcı Memnuniyeti: Konya Örneği, Yüksek Lisans Tezi, Gazi Üniversitesi, Fen Bilimleri Enstitüsü, Mimarlık Anabilim Dalı, Ankara 2015.

Durmuş Eda, Kahve kültürü Ekseninde Günümüz "Kafe"lerine - Nişantaşı Merkezli Bakış, Yüksek Lisans Tezi, T.C Mimar Sinan Güzel Sanatlar Üniversitesi, Fen Bilimleri Enstitüsü, İç Mimarlık Anabilim Dalı, İstanbul 2010.

Ergin, Dirun, Gelişen Teknoloji Işığında Performans Mekânlarında İşitsel Konfor Gereksinimleri Ve Akustik Tasarım Yaklaşımları, T.C. Yıldız Teknik Üniversitesi, Yüksek Lisans Tezi, İstanbul 2014.

Özil, Elif, Hasta Yatak Odalarında Görsel Konfor Koşullarının Örneklerle İncelenmesi, T.C. İstanbul Teknik Üniversitesi, Yüksek Lisans Tezi, İstanbul 2008.

Al, Selda, Eğitim Yapılarının Fiziksel Konfor Koşullarının Öğrenci Başarısına Etkisi, Karadeniz Teknik Üniversitesi, Doktora Tezi, Trabzon 2014.

Altay, Burcu, Mekân Ambiyansı Bağlamında Kafe Restoran Tasarımındaki İç Mekân Detaylarının Kullanıcı Algısına Olan Etkisi, Yüksek Lisans Tezi, T.C Bahçeşehir Üniversitesi, Fen Bilimleri Enstitüsü, İç Mekân Tasarımı Bölümü, İstanbul 2014.

Güvensoy, Çiğdem, Kurum Kimliği ve Kafeler, Yüksek Lisans Tezi, T.C Mimar Sinan Güzel Sanatlar Üniversitesi, Fen Bilimleri Enstitüsü, İç Mimarlık Anabilim Dalı, İstanbul 2008.

Kuş, Mehmet, Şanlıurfa İlindeki Yüksek Öğrenim Kurumları Dersliklerinde lç Hava Kalitesinin Incelenmesi ve Modellenmesi, Yüksek Lisans Tezi, T.C. Balıkesir Üniversitesi, Mimarlık Fakültesi, Balıkesir 2017. 
Bajmaku, Ajhan, Kahve Kültürü Ve Kahvehane Mekânlarının Sosyol Kültürel Ve Politik Yaklaşımlar Ille Popüler Kültür Çerçevesinde Değerlendirilmesi: Kosova Örneği, Doktora Tezi, T.C Mimar Sinan Güzel Sanatlar Üniversitesi, Fen Bilimleri Enstitüsü, İç Mimarlık Anabilim Dalı, İstanbul 2014.

Coşkun, Ahmet, Antalya Ilinde Farklı Ortamlarda Iç hava Kalitesinin Araştııılması ve Modellenmesi, Doktora Tezi Balıkesir Üniversitesi Fen Bilimleri Enstitüsü Makina Mühendisliği Anabilimdalı Balıkesir 2012.

Şahinoğlu, Selin, Gölge Elemanlarının Pencerenin Isıtma/Soğutma Enerjisi Ve Görsel Konfor Performansına Etkisinin Değerlendirilmesi, T.C İstanbul Teknik Üniversitesi, İstanbul 2012.

Güler Hande, Ülkü Sedat, Bitişik Nizamlı Villa Tipi Konutlarda Yapısal Konfor Koşulları Üzerine Bir Araştırma, Uludağ Üniversitesi Mühendislik-Mimarlık Fakültesi Dergisi, Cilt 12, Sayı 2, 2007

Manav Banu, Küçükdoğu Mehmet Şener, Aydınlık Düzeyi ve Renk Sıcaklığının Performansa Etkisi, İtü Mimarlık, Planlama, Tasarım Dergisi, Cit:5 Sayı:2, Kısım:1, 310, 2006

Celasin, Cenk, Popüler Müzik Tüketimi Bağlamında Isparta Merkez'deki Canlı Müzik Sunan Kafelere Genel Bakış, DOI: 10.7816/idil-02-08-09

Özdamar Melek, Umaroğulları Filiz, Bir Ofis Yapısı Örneğinde Isıl Konfor ve İç Hava Kalitesinin Incelenmesi, Megaron Dergisi, Cilt:12, Sayı:1, 2007

Şenkal Sezer Filiz, Vural Arslan Tülin, Çahantimur Arzu, Alışveriş Merkezlerinde Kullanıcı Memnuniyetinin Konfor Koşulları Açısından Değerlendirilmesi: Bursa Örneği, Uludağ Üniversitesi Mühendislik-Mimarlık Fakültesi Dergisi, Cilt 19, Sayı 1, 2014

Şenkal Sezer Filiz, Vural Arslan Tülin, Eğitim Yapılarında Fiziksel Çevre Kalitesinin Kullanıcı Memnuniyeti Açısından Değerlendirilmesi, Uludağ University Journal of The Faculty of Engineering, Vol. 21, No.2, 2016

Üçok, Ahmet Kemal, Türkiye'de Kahve ve Kahvehaneler, Türk Etnografya Dergisi, Sayı:5, 1962

Yüksek İzzet, Mıhlayanlar Esma, Tıkansak Tülay Esin, Konut Kullanıcılarının Iç Ortam Konfor Koşullarından Memnuniyetlerinin Tespitine Yönelik Bir Çalışma, Teskon 2015 I Bina Fiziği Sempozyumu

Fanger, P., O. Thermal comfort: Analysis and applications in environmental engineering. Danish Technical Press. 1970.

Hattoc, Raphl S. Kahve ve kahvehaneler. Bir toplumsal içeceğin Yakındoğu'daki kökenleri, Tarih Vakfı Yurt Yayınları, 1988

Heıse, Ulla, Kahve ve Kahvehane, Çev. Mustafa Tüzel, Ankara: Dost Yayınları, 2001

Bingül, İlyaz, Kahvenin Anlamı, Cogito, Sayı: 68-69: 328-349, 2011 